\title{
Analogical Evidence and Shamanism in Archaeological Interpretation: South African and European Palaeolithic Rock Art
}

\author{
MARÍA CRUZ BERROCAL
}

Rock art studies have been strongly reliant on ethnography in recent decades. Since the 1970s, the (re)turn to ethnography has been considered short of a paradigmatic change, and it has indeed stirred a lot of theoretical discussion in the very under-theorized field of rock art research. The ethnographic turn has been mainly built around shamanism, very loosely defined here as the causal association that researchers establish between shamanic practices and rock art, and from which explanations have been sought. The application of this approach has changed through time, depending on 1) the archaeological context in which it was to be applied, 2) the use of additional sources of evidence (namely, neuropsychology), 3) the role of shamanism as a hypothesis or as an established fact. As a hypothesis it has been built on the basis of three different kinds of analogies: ethnographic, formal and uniformitarian. This paper addresses the shifting character of shamanism in South African and European Palaeolithic rock art studies, seeking to contribute at least in part to a broader reflection on the nature of analogical reasoning and its implications.

\section{INTRODUCTION}

This paper is a historiographic revision of the application of a shamanistic hypothesis, henceforth 'shamanism', to rock art studies, especially in the South African and the Western European Palaeolithic rock art corpora. Shamanism is understood here as the association that researchers have established since the 1970s between shamanic practices $^{1}$ and rock art, even if it was not explicitly labelled as such. ${ }^{2}$ This association implies a causal relation, because rock art was explained as the product of shamanistic practices.
This paper highlights the role that analogy plays in shamanism, and its changing nature through time. The term shamanism hides not only different analogies, but also different theoretical approaches to the social significance of rock art. Ultimately, shamanism is a paradigmatic case study for further inquiry into the use of analogy in archaeological research to be explored in the future.

Analogical arguments, especially those of an ethnographic character, have been present in rock art research from its very beginnings. Ethnographic information from disparate parts of the world was employed in

María Cruz Berrocal, Research Group on Social and Economic Prehistory, Instituto de Historia, Centro de Ciencias Humanas y Sociales, CSIC Madrid, 28037, Spain. E-mail: maria.berrocal@cchs.csic.es 
rock art research in Europe and was also essential to its early study in places such as South Africa, as researchers recorded the San language and its related oral history at the end of the 19th century. They suggested that the rock art 'illustrated' accounts of indigenous myths, daily-life scenes, folklore, customs or superstitions (W. Bleek, cited by Lewis-Williams 2006a:352, see also LewisWilliams 2000).

However, the use of ethnographic information was not without problems. In Europe, the use of ethnographic information was eventually discredited due to the abuse of analogical arguments, characteristic of early evolutionist and culture history archaeology (Wylie 1985, Lane 2006). Distanced from the ethnographic sources, researchers used this information in a non-systematic way and did not take into account the quality of those sources. Back in the original areas where ethnographies were recorded, such as South Africa, Australia (Vinnicombe 1995) and USA (Whitley 1994), ethnographic records had been early dismissed for several reasons including difficulties on the part of the researchers in understanding the information and their scepticism about the quality of ethnographic descriptions. The loss of the original indigenous interpretations and true meaning of the depictions contributed to this scepticism, since researchers tended to assume that only the artists were able to tell the true meaning of their work. But, ultimately, ideological reasons and sheer racism on the part of colonial societies and researchers (Layton 1995, Lewis-Williams 1995a, Vinnicombe 1995) led them, especially in South Africa, to disregard both rock art and the associated ethnographic information as meaningless. The only value of rock art was that it was 'primitive' (Jarl Nordblah, pers. comm.).

Thus, it is almost ironic that the (re)turn to anthropology/ethnography led by South African researchers in the 1970s was hailed as 'revolutionary' in rock art studies (see Morwood \& Hobbs 1992, also Conkey 1997) and considered to be nothing short of a paradigmatic change:

A ... marked rise in success would begin in the early 1970s, when an ethnographic approach, seasoned with social theory, began to be adopted and which, over the next three decades and more, produced results that constituted the foundation for new theory and method. (Lewis-Williams 2006a:369)

The core of this new foundation was shamanism, presented as sound ethnographic analogical reasoning for the first time, and therefore a real improvement over the previous empiricist research (Lewis-Williams 1991, 2006a).

This re-adoption of ethnographic information and the application of analogy in rock art research in an explicit and thoughtful manner in the 1970s (Lewis-Williams \& Loubser 1986, Lewis-Williams 1991) had a precedent in the 1950s debates over the necessity of making safe inferences and the status of analogy in mainstream archaeology (Wylie 1985). As a result of these debates, the value of analogy was firmly established, and in the 1960s ethnoarchaeology as a sub-discipline emerged (Lane 2006). Thus, the return to analogy as a mode of reasoning in rock art research was a slightly late development. While this turn to ethnography may have been partially the result of a general trend in archaeology, other factors certainly contributed to it, such as the relative exhaustion of the previous theoretical frameworks and a change in the political climate of the 1970s, representing a re-evaluation of indigenous peoples' past and present.

Next, I will briefly address these two factors in order to better contextualize the subsequent discussion of shamanism.

\section{FRAMEWORKS}

Culture-historical archaeology provided an omnipresent theoretical framework for rock art studies, from which a range of different interpretations, such as hunting-magic or the art-for-art's-sake hypotheses, were produced. 
Its underlying principle was rooted in the notion that rock art resulted from the innate expressiveness of human beings, who naturally tend to make their feelings and their cultural norms known through art and shared stylistic traits. Style is therefore an important object of study, since it is seen as part of the common cultural heritage shared by one people. In this context, style is used at the same time as a) chronological indicator, b) expression of the degree of development or cultural and social 'stage' of a social formation and c) expression of ethnicity. Style and rock art are then major components of cultural expression, apt to define peoples, cultures and territories. But this approach to rock art minimizes its relevance in social terms because it is treated as an inherent human manifestation, rather than a historical, social and political one.

The New Archaeology triggered a critical approach to the concept of style (Conkey \& Hastorf 1990), whose role was now to be understood in terms of function, adaptation and information (Conkey 1980, 1984, 1985, Mithen 1987, 1991, Barton et al. 1994). Rock art was regarded as an adaptive phenomenon used to transmit information, within and outside the social group. It was assigned a place in the social system as a manifestation within the ideological and symbolic subsystem, thought to have eased social and ecological pressures. In this way, rock art was related to other spheres of human behaviour rather than being an individual's artistic expression.

At the same time structuralism had showed its relevance for rock art studies since the 1960s (for instance, Conkey 1989, Criado \& Penedo 1989, Leroi-Gourhan 1992, Sauvet \& Wlodarczyk 1995, Santos 1999). Rock art seemed to lend itself very well to structuralist logic, due to its alleged entirely intentional and symbolic character. It would be a direct manifestation of people's structures of thought and past worldviews, unlike other sorts of archaeological record.

Both functionalism and structuralism had limits, though. On the one hand, system theory was incapable of reaching the specific meaning of the depictions. On the other hand, structuralism tended to fall into an interpretative excess. Hence, the use of ethnographic analogy, and particularly of shamanism, arose as an ideal middle ground (Lewis Williams 1995a). Shamanism approached and treated social aspects and symbolic contents at the same level. Its controlled use of the ethnographic evidence (Lewis-Williams \& Loubser 1986, Lewis-Williams 1991) helped reveal the meaning of rock art, avoiding speculation and embedding this search for meaning in a general aim to understand its function as part of social life (Lewis-Williams 1982).

The application of shamanism was based on functionalism and structuralism, as well as Marxism, since there was a recognition that social life is not necessarily harmonious (Lewis-Williams 1995a:77). Social struggle became a key characteristic of original shamanic interpretations. Ultimately, the use of Marxist principles was also an attempt to raise social concern among rock art researchers (Lewis-Williams 2006a:366).

The political climate of the 1970s in South Africa contributed to the success of shamanism because the use of information provided by native people, who had previously been neglected, was now reinstated together with the value of indigenous knowledge. This had positive political consequences in the long run (Lewis-Williams 1995b, 2006a) since respect was now granted to those 'primitive' communities who created the artworks. Currently, rock art is clearly a most conspicuous element of South African heritage (Fig. 1).

With this change in the intellectual and political attitude towards indigenous groups came an important change in academic leadership in rock art studies. Rock art throughout the world had previously been interpreted following the European lead. This situation was successfully reversed by South African researchers, and European rock art was eventually interpreted after their approach.

It is well known, however, that shamanism has a long history of harsh, repetitive and 


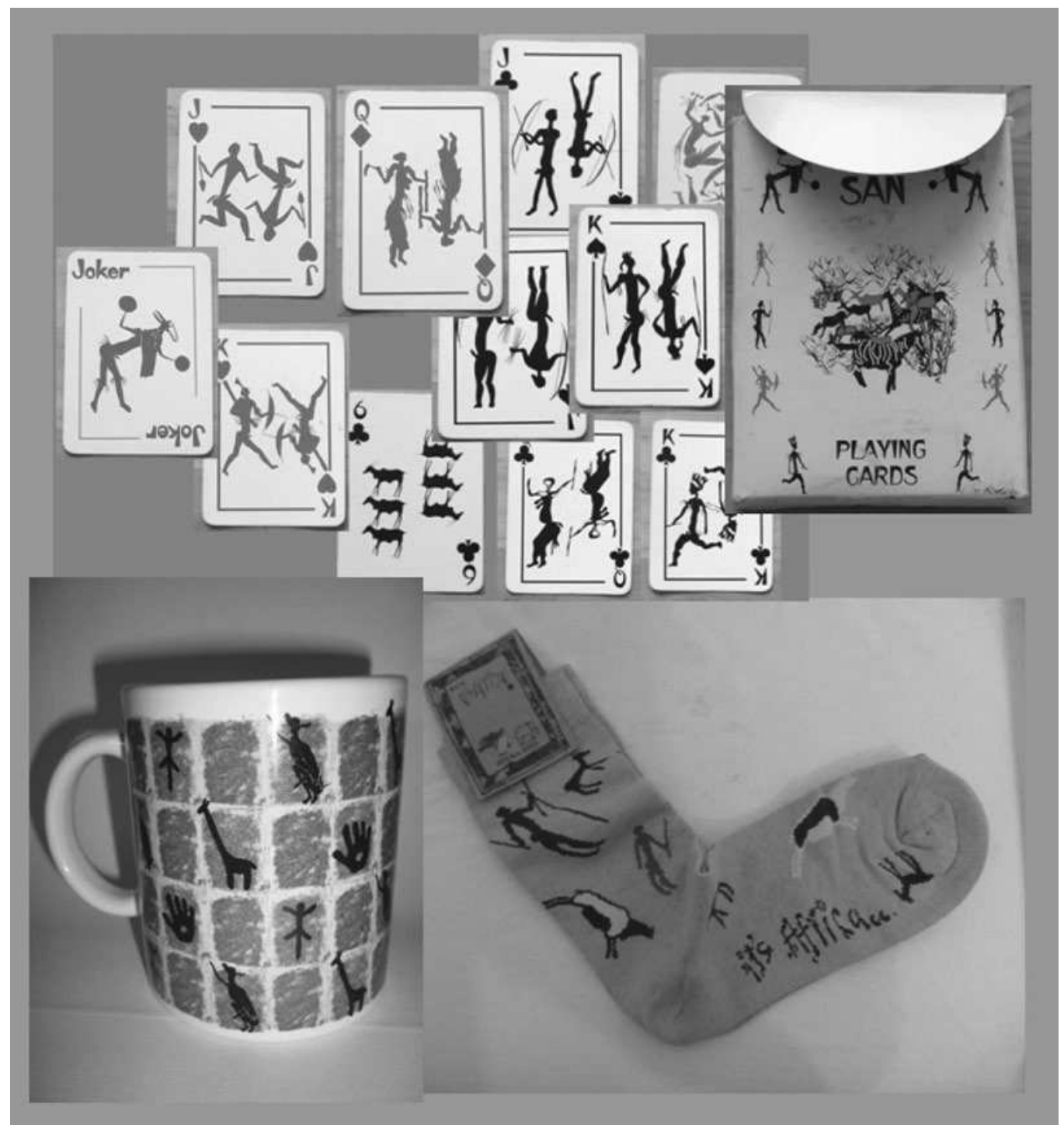

Fig. 1. South African merchandising with rock art motifs.

extensive criticisms, counter-criticisms, replies and counter-replies (see Meighan 1982, Sauvet 1989, Bahn 1993, 1997, Demoule 1997, Hamayon 1997, Beaune 1998, Solomon 1998, 2001, 2008, Vialou 1998, Taborin 2000, Francfort 2001a, 2001b, Francfort \& Hamayon 2001, Le Quellec 2001, Lorblanchet 2001, Helvenston and Bahn 2004, McCall 2007; see replies in Lewis-Williams 1991,
1999, 2003, 2004a, 2004b, 2006a, 2006b, Lewis-Williams \& Clottes 1998b), with the most aggressive attack unleashed by the publication of Les chamanes de la préhistoire, by Jean Clottes and David Lewis-Williams (Clottes \& Lewis-Williams 1996). Some of the most important problems that have been pointed out in this debate refer to the speculative character of shamanism, ${ }^{3}$ 
its lack of historical context, ${ }^{4}$ its reliance on scarce ethnographic evidence and, most importantly, its lack of explanatory power (Francfort 2001a, Bahn 2001, Le Quellec 2001, McCall 2007) and lack of testability (Sauvet 1989, Bahn 1997, Francfort 2001a, 2001b). Some radical proposals ask for a return to empiricism in light of the problems of shamanism (Bahn 2001:81). As a whole, however, the debate on shamanism has been useful because it has helped to address issues about cultural contact and cultural continuity/rupture of hunter-gatherers' lifeways, and about the need to make explicit our research procedures (Lewis-Williams 1984, 1999, 2006a, Dowson 1994). I do not wish to engage in a general critique or defense of shamanism in this paper, but in a discussion on its use of analogical reasoning. Likewise, I am not concerned here with other related problems, such as the pervasive association between rock art and hunter-gatherer societies in the literature in spite of the fact that the bulk of the rock art in the world was not made by hunter-gatherers (Cruz Berrocal \& Millerstrom 2010; for the case of South Africa see Smith \& Ouzman 2004), or the analysis of the application of shamanism in Scandinavia (Tilley 1991, Helskog 1999, Lahelma 2005, 2007), Central Eurasia (Francfort 1998, 2001b) and other areas where a direct historical approach seems feasible, and where independent developments as well as points in common with the topic of this paper create a particular historiography worth exploring.

\section{ANALOGY}

I shall use the following simple definition of 'analogy': an analogy is a comparison between two parallel phenomena, one of them, in our case, being an archaeological object of study. This comparison helps archaeologists build a hypothesis to understand their object of study, the assumption being that if the two terms of comparison are similar in one or more respects, then they must be equivalent in others. Of course the term of comparison used by archaeologists must provide additional information about the structure of the archaeological object, its genesis, its use and so on.

Analogy cannot be considered an explanation. It just highlights regularities and/or associations that need further inquiry. It does not solve a problem; it helps formulate the correct question. Ultimately, it requires other kinds of evidence to be meaningful.

Two quotations from Lucas (2001) are pertinent to further clarifying this aspect of analogy. They point to the fact that an analogy must allow the existence of differences, in a way that makes:

the subject . . . both the same and not the same as the source. The tension between these two terms is not open to qualification in terms of the degree of similarity, whether formal or relational. To become obsessed about such degrees of similarity, is to substitute analogy for equivalence ... . the important point is that analogy, as analogy, should not be prefigured by equivalences in the form of boundary connections or connecting principles, as this robs it of its very nature. It suggests moreover that our use of analogies does not need strengthening. (Lucas 2001:192).

Wylie herself points out that analogy is not just about similarities but also about differences - the fallacy of the 'perfect analogy' is that such a thing is not an analogy at all (Wylie 1985). The point about an analogy in other words is that it does not mark an equivalence between two terms (source and subject) but merely a resemblance. (Lucas 2001:191)

Different kinds of analogy are based on the use of different terms of comparison. I will briefly deal here with what I term ethnographic analogy, ${ }^{5}$ formal iconographic analogy and formal uniformitarian analogy, as they are pertinent for my subsequent discussion of shamanism.

Ethnographic analogy is a comparison between an archaeological object under study and ethnographic data provided by indigenous informants. But ethnographic information varies in character. It can be 
historical, collected in the recent or distant past. The criteria used to record the information do not necessarily match current research needs. Sometimes these needs necessitate re-elaboration in order to be useful.

On the other hand, ethnographic information can be collected for the explicit purpose of a particular archaeological investigation. But, since most traditions died long time ago, as a general rule historical ethnographic information is pre-eminent within rock art studies.

Ethnographic information can also be direct, when both the archaeological and ethnographic contexts share a common geographic setting and a potential cultural connection exists between them. In the absence of a continuous historical connection, a geographic link can still make ethnographic information useful because it can be used as a source of 'structural' information; for instance, it can provide hints about landscape uses or other basic properties of the landscape. But there are no absolute criteria to define an ethnographic analogy accurately based on the character of the ethnographic information. On many occasions it is a matter of degree and scale, ultimately dictated by what is a meaningful temporal or geographical setting. This can make the analogy susceptible to criticism because it can be perilously overextended.

Formal analogies are established on the basis of straightforward similarities between two objects. In the case of rock art, the analogy is based on iconographic similarities; hence my term formal iconographic. It is applied as two motifs are compared and found alike in some sense or another. A similar origin for both motifs is then inferred from this resemblance (i.e. they are supposed to be made by the same person or under the same circumstances). Resemblance, in sum, can be subject to different interpretations.

A uniformitarian (Lane 2006) analogy is, as a general rule, based on the use of an underlying assumption of universalism, i.e. a process that operates in the present must also have operated in the past. A formal uniformitarian analogy is then a variation of a formal iconographic analogy because it is intended to explain iconographic similarities but, unlike a formal iconographic analogy, its application necessarily entails the explanation of those similarities, embedded in the uniformitarian principle. In the case of shamanism, this principle is that Homo sapiens sapiens have similar brain structures and nervous systems and therefore their reactions under certain stimuli are similar (Lewis-Williams 1991:153). Therefore, similar stimuli must produce similar depictions. This formal uniformitarian analogy is known as the "neuropsychological model'. The scope of a uniformitarian analogy should be carefully established to avoid the obvious danger of taking for granted what should be formulated as a research problem.

In the next section I discuss how the nature of shamanism mutated across these different types of analogies. It is important however to point out that an analogy is a way of creating evidence, and that its value depends on the research questions as much as on the nature of the comparison. It is ultimately the broader theoretical framework which determines how and why the analogy is established.

\section{THE CHANGING CHARACTER OF SHAMANISM}

The application of shamanism to rock art has grown and become more complex through time. This complexity can be understood by observing shamanism in three stages, each presenting particular significance and implications.

\section{SHAMANISM AS ETHNOGRAPHIC ANALOGY}

There are arguments for considering shamanism, as it was originally defined, as a middlerange theory ${ }^{6}$ under an explicit functionalist framework.

Shamanism was originally presented (see Lewis-Williams 2006a for an extended account) as a hypothesis used to approach 
the understanding of South African rock art through the use of ethnographic texts to shed light on the rock art depictions. These texts described the activities and beliefs of certain social groups and particularly of certain individuals, emphasizing practices generally considered as shamanic. Thus, a general shamanic background was established for South African past societies and consequently for rock art.

Shamanism used two kinds of ethnographic accounts: historical and contemporary. The historical ethnographic accounts tended to belong to the same geographic setting as the rock art broadly speaking, while the contemporary texts about shamanic practices tended to belong to neighbouring areas such as the Kalahari Desert, where there is no rock art.

Historical ethnographic texts (mostly produced by W. Bleek, L. Lloyd and J. M. Orpen) were used to imply the existence of direct cultural continuity between the societies that made the rock art in the past and the providers of the ethnographic data. But the link between rock art and ethnographic records was not straightforward. On the one hand, the majority of written sources had been collected from peoples with no living tradition of rock art. Although the informants made direct mention to rock art in a few cases, they were seldom the artists. Reliance on native accounts, therefore, was not a sufficient condition to validate the use of ethnographic sources since the indigenous knowledge in this case was secondary. On the other hand, the activities, practices and beliefs mentioned in these texts were interpreted as shamanic only in the 1970s; previous researchers did not observe this possibility (Bahn 1997).

But, once the interpretation of the texts as accounts of shamanic activities was established, it opened the possibility for researchers to propose a comparison between the texts and the rock art, since some descriptions were relatively easy to identify on the panels. These were descriptions of transitional states between animal and human, ${ }^{7}$ and of the eland (an African antelope), very abundant in the written records. These elements were convincingly identified in the rock art compositions, which allowed researchers eventually to extend the range of motifs and features that could be 'understood' using texts, such as dances, blood coming out the nose, lines of force, fantastic creatures such as the rain animal, some body poses and gestures, and the use of cracks or other characteristics of the rocks as part of the compositions. Most importantly, these iconographic parallels pointed towards the symbolic character of the rock art motifs and their role in certain ritual activities. An eland for instance could have as its ultimate referent a mythical being and so on.

Rock art was subsequently interpreted as a way to convey spiritual energy and as 'recreations of spiritual or supernaturally potent entities that could be touched and from which people could draw power' (LewisWilliams 2006a:365). The depictions were considered to be part of religious rituals developed by shamans, intended for healing or rain making, among other functions. In turn, rock art places were interpreted as being the appropriate settings for these activities due to alleged supernatural characteristics. Rock shelters became associated with hidden knowledge made public through the action of the artist, who in turn was thought to be equivalent to a religious specialist. The artist would interact with transcendent realities and communicate with spirits in rock art places (Lewis-Williams 1981).

Bridging the gap between ethnographic texts and rock art was an analogical exercise. The texts did not render information on rock art in a direct way, but they allowed researchers to partially reconstruct a society under pressure from colonialism, especially their practices in relation to shamanic beliefs. In turn, this reconstruction helped with the understanding of the material record (rock art) left by past prehistoric societies given that the interpretation of the depictions was reasonably secured through the texts. 
Researchers then could move on from the rock art itself and its interpretation to its context of production in the past, i.e. shamanic rituals. Rock art was therefore inserted into a broader context, expanding the research focus to the understanding of the social significance of shamanism. The final goal of shamanism was to learn about specific cultural meanings of depictions only as a way to understand the rock art and its social implications.

Therefore, this initial shamanism provided the bridge that allowed researchers to build a chain of inferences from rock art to its production and, ultimately, to the social context of this production. This description of social context drew from social theory, system theory and Marxism (Lewis-Williams 1982, 1995a), i.e. the analogical reasoning was embedded in a broader theoretical framework and explaining rock art was ultimately equivalent to explaining the social formation that made it. But rock art was not just a by-product of certain social practices; it was also an archaeological evidence that rendered information about the social formation that made it, because it was interpreted as a locus of conflict: 'The art became an instrument of change and an index of social diversity and conflict - a very different picture from the harmonious one projected by functionalist perspectives' (Lewis-Williams 1995b:81). Rock art and rituals were ultimately considered social devices intended to release social tension, drive negotiations among different groups, alleviate conflict and negotiate status (Lewis-Williams 1980, 1982, 1995b, Blundell 1996, Dowson 1994, 1998). Ultimately, the existence of rock art was taken as an evidence of social struggle; its interpretation was intimately linked to the understanding of the economic and social context (Lewis-Williams 1982).

This particular interpretation of rock art shamanism made can be discussed on theoretical grounds, but potential disagreement in this sense does not affect the soundness of the analogy. It showed possible associations but it did not have to demonstrate them. Researchers always acknowledged that depictions could possibly have other meanings, inaccessible through ethnographic texts.

Shamanism, in sum, played the role of middle-range theory because it enabled a chain of linked assumptions that acted as bridging arguments of a general hypothesis. The chain of inferences that supported the social interpretation of rock art within the San social formation was reasonable. The hypothetical shamanic character of rock art was explicit and the hypothesis as a whole was plausible in this context.

\section{SHAMANISM AS FORMAL ICONOGRAPHIC AND FORMAL UNIFORMITARIAN ANALOGY}

The next stage in the life history of shamanism is marked by its application outside its original South African context, especially to European Palaeolithic paintings. Within this context the ethnographic character of the hypothesis was downplayed in order to emphasize elements that could support its application to Western Europe. It was now the turn of formal parallels and the so-called altered states of consciousness, ${ }^{8}$ or the neuropsychological model, to become the central focus of attention.

According to this model, altered states of consciousness, originating in a malfunctioning of the brain, explained the geometric depictions known as entoptics or phosphenes (Lewis-Williams \& Dowson 1988) (Fig. 2). They undergo three phases. The first, allegedly induced through the use of certain hallucinogens or other practices, results in visions of undulating lines, grids, and nested curves. This phase is obviously very important for the interpretation of rock art.

In the second stage, individuals may ascribe meaning to these geometric forms, and in the final third stage, people are said to have visions of other "people, animals and monsters, as well as hallucinations in all the senses; 
Experimental entoptics

SAN, SA PALAEOLITHIC, WESTERN EUROPE

\begin{tabular}{|c|c|c|c|c|c|c|c|}
\hline 梧 & reson & 14. & 离 & 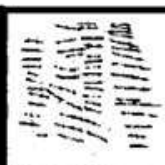 & $-a$ & $y^{\circ}$ & $\begin{array}{c}\text { 田 } \\
\text { 用 }\end{array}$ \\
\hline & $=$ & "): & & & $\left(\begin{array}{ccc}1 & 1 & 1 \\
1 & 1 & 1 \\
1 & 1 & 1 \\
1 & 1 & 1\end{array}\right.$ & , 11 & $H_{1}$ \\
\hline $0^{\circ} \circ \circ$ & 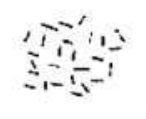 & י4: & & & 作 & sen & $\begin{array}{l}\because / N \\
=1 "\end{array}$ \\
\hline and & 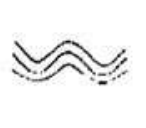 & & & M M & ANי & $\sum_{3}$ & {$\left[\begin{array}{c}\pi x \\
\vdots\end{array}\right.$} \\
\hline$y$ & $\widehat{3}$ & ث & & 3 & $\approx \cong$ & : & wo \\
\hline जह & & nosson $\rho$ & & & & & \\
\hline
\end{tabular}

Fig. 2. After Lewis-Williams \& Dowson (1988). Printed with permission from University of Chicago Press.

subjects participate in their own imagery. Geometric imagery may now be peripheral or combined with iconic images. The third stage is frequently reached by seeming to pass through a vortex or tunnel, or by a sensation of flight' (Lewis-Williams 2004a:107).

In theory, and in spite of the physiological emphasis entailed by the neuropsychological model, entoptics in rock art should be considered to be the result of the interplay between the inherent structure of the brain and particular cultural contexts, even under an altered state of consciousness (Lewis-Williams \& Dowson 1988). In fact, however, universalism prevailed over any sort of cultural particularism and the human nervous system was prioritized over culture. This was the only way to establish a meaningful comparison between entoptic motifs seen by contemporary people under experimental conditions and the South African rock art corpus. Positive correlation was taken to be a proof that these rock art motifs, previously unexplained in the absence of ethnographic information directly associated with them (Layton 2000:174), had been produced by people in an altered state of consciousness, i.e. by shamans. At the same time, lack of a perfect fit between images would be the product of particular cultural contexts and would allegedly not weaken the analogy (Lewis-Williams 1991, Lewis-Williams \& Dowson 1992).

As a result, the neuropsychological model was regarded as independent evidence that 
allegedly made the analogy stronger, based on formal iconographic similarities between experimental images and South African rock art motifs. This new take on shamanism was to be applied to other non-ethnographic rock art corpora elsewhere in the world, particularly to European Palaeolithic rock art (Lewis-Williams \& Dowson 1988, 1992, Clottes \& Lewis-Williams 1996, LewisWilliams \& Clottes 1998a), where geometric depictions had often gone unexplained.

By then, the nature of shamanism had obviously switched from an ethnographic direct historical approach to a formal one, based on the geometric nature of the depictions, although some iconic depictions began to be increasingly interpreted as shamanic (LewisWilliams 1991, Lewis-Williams \& Dowson 1992).

Formal analogy and the neuropsychological model became the mechanisms that allowed the application of shamanism to the European Palaeolithic. But the substitution of an ethnographic analogy by a formal one under the same label, shamanism, triggered harsh criticisms against it, as its proponents were accused of speculation and ill use of the analogy in order to describe many (ambiguous) depictions in shamanic terms. Indiscriminate use of formal iconographic analogies even brought criticisms of South African proponents of shamanism (Blundell 1998, Lewis-Williams 2006a). ${ }^{9}$

This wave of criticisms was to be expected because, even though a formal analogy is part of middle-range theory strategies that can be accepted when justified (see Lewis-Williams 1991:158, and favourable critiques in Barich 1996:10, Trigger 1995:455), it is weaker than an ethnographic analogy because it is based on subjectively defined iconographic similarities without further context. For instance, critics (Francfort 2001a, Bahn 2001, but see reply in Lewis-Williams 2004a, 2006a) have pointed out that geometric motifs are not necessarily entoptics, and entoptics are not necessarily a product of altered states of consciousness. Many circumstances, besides trance, may produce them, so it should not be possible to tell a shamanic from a nonshamanic context (contra Whitley 2005:122).

Moreover, the assumption of independence for the neuropsychological model is problematic, because it actually depends on the previous establishment of a shamanic interpretation of the rock art, i.e. it depends on a previous ethnographic analogy.

For these reasons, other lines of evidence must be added, as was the case with the shamanic interpretation of the European Palaeolithic rock art, where more arguments were later supplied (see Lewis-Williams 2002, Whitley 2005). Unfortunately, archaeological arguments for the existence of shamanic practices tend to be inconclusive.

In sum, as shamanism mutated from a South African direct historical approach to a purely formal analogy in the case of European Palaeolithic rock art - literally and metaphorically moving outside its original context - it became weaker as it relied on longer chains of inference and the articulation of different kinds of analogical reasoning. More accurately, weakness arose because the scope of the interpretation - that the rock art is the product of shamanic practices, and therefore shamanism was a fundamental pillar of San and Palaeolithic societies - did not change according to the power of the analogy in use.

\section{SHAMANISM AS TRANSLATION}

In theory, shamanism is still considered a hypothesis that aims to understand South African San rock art based on an ethnographic analogy and in this sense it could be subject to further testing (Lewis-Williams 2006a). However, the abundance with which shamanism has been applied in many different archaeological contexts all over the world has had the effect of strengthening the validity of the original hypothesis in South Africa. Most of the criticisms that it has received (see Jolly 1996, Solomon 2001, 2008, Dowson 2007; see also Layton 2000) have targeted the content of the interpretation but 
have not questioned its validity as a method. They mostly point that not all San rock art would have been produced by shamanic practices, advancing alternative interpretations also based on ethnographic accounts (Dowson 2007, Solomon 2008). These are, however, less robust than shamanism, whose pre-eminence, being more systematic, has not been threatened, as Layton points out: 'Lewis-Williams' reading is more persuasive because more details of the composition are read in a way consistent with the available ethnography for the region and no details contradict the preferred reading' (Layton 2000:171).

In reality, shamanism is no longer used as a plausible hypothesis; instead, it has acquired the status of a fact (see LewisWilliams (1996:291) or Whitley - 'The San of southern Africa are very well known for their shamanic rock art' (Whitley 2005:98)). The original hypothesis interpreting San rock art as shamanic has tacitly been accepted as being correct by a majority of researchers. As a result, oral narratives collected in ethnographic records and rock art have become different channels of the same communicative process. Consequently, current research is focused on the transposition of meaning from the ethnographic and textual context to the archaeological one. Both are seen as two sides of the same experience, of the same phenomena: the shamanic practices. Thus, shamanism, or properly speaking religion, is the fundamental focus of research, and rock art becomes supplementary evidence of its existence.

If we stick to the definition of analogy given above, regarding what an analogy is and does, the original analogical character of shamanism should be reconsidered. As it is now applied, shamanism has conflated the two terms of the comparison into a single phenomenon. Thus, the possibilities of showing contrast, similarities or differences, maybe even principles of connection or relational properties between them (Wylie 1985), have been eliminated and substituted by an act of translation, i.e. using the ethnographic records to interpret signs and assigning concrete, finite meanings to the rock art motifs.

Through this set of mutations, shamanism may be identified as a case study that demonstrates how the original use of ethnography as a source of analogy has eventually led to non-analogical reasoning ${ }^{10}$ while the focus of research, i.e. the interpretation of rock art, remained the same.

\section{IMPLICATIONS}

Shamanism conflates theories and analogies of very different characters. Initially, the original ethnographic analogy was posed as an epistemological bridge to explain rock art in its social context and historical conjuncture. It later became a formal iconographic analogy when it was applied to the different temporal and geographical context of European Palaeolithic art. At the same time, it mutated again to become a uniformitarian analogy used as an alleged independent kind of evidence. Finally, shamanism became an exercise in exegesis of the meaning of the depictions through the use of ethnographic texts. These different kinds of reasoning can be associated to a broader theoretical change, from the initial materialist framework of shamanism to what we could consider properly an idealist one - or post-processual due to its emphasis on symbolism and meaning (see Barich 1996, McCall 2007:226).

This shift has raised a series of issues. First, the strength of the analogy has suffered as its character has changed, and this needs to be explicitly acknowledged by researchers since it has an impact on its heuristic power. As the nature of the analogy became weaker, its associated interpretation should have been accordingly limited.

Second, shamanism tends to conflate epistemological categories such as explanation, theory, analogy, method (e.g. it is a 'new theory and method' (Lewis-Williams 2006a:369)), and facts. A more explicit epistemological definition of shamanism is 
probably needed, especially about the current status of shamanism regarding the available evidence.

Third, it has been acknowledged many times that emic approaches might privilege the vision of a specific individual or group of individuals over the rest of the group, by focusing on the one particular meaning available. Meaning is polysemous and the relation between meaning and material sign is not univocal within the same social group. Knowledge may be unevenly distributed inside the social group. Therefore, there is the danger that ethnographic records might be biased, masking differences in knowledge and/or power. In shamanism this point might be complicated by the fact that it was mainly not the makers of the rock art who provided information. Placing too much emphasis on the centrality of texts as opposed to empirical observations from the archaeological record can further exacerbate these problems.

And, fourth, as an ethnographic or uniformitarian, direct historical, formal or hermeneutical approach, shamanism depends on underlying assumptions that point to different research goals. In my view, it has evolved from a functionalist interpretation of rock art, with a focus on conflict as inherent in the social role of artistic production, to become an inquiry about spiritual and religious concerns and activities of individuals (e.g. Bertilsson 1995, Whitley 2001, 2005, Whitley \& Keyser 2003, Jones 2003, see also Trigger 1999).

Rock art is generally regarded as a privileged means of accessing the symbolic realm, and seems to lend itself to interpretative meaning-oriented approaches, as 'archaeological settings saturated with "art" and "ritual", lend themselves to meaning-oriented analysis (Robb 2007:73). But, as many materialist-framed works show (Conkey 1980, Lewis-Williams 1982, Jochim 1983, Gilman 1984, Mithen 1987, 1991, Rosenfeld 1997), rock art was not always regarded as a mere provider of evidence for the existence of religion in prehistoric societies, and its study was not always seen as an archaeology of religion (see Palacio 2010) or as a quest for meaning (see also Balbín \& Alcolea 1999, Balbín 2007). These have become essential issues in rock art research as social archaeology (namely functionalism and Marxism) has lost appeal and a practice rooted in thinking in terms of individuals and agency has gained terrain. In this regard, it is also likely that the relevance of the neuropsychological model in shamanism contributed to this change in focus. The emphasis given to the human nervous system, its universality and its apparent explanatory power tend to stress the role of the individual/artist (Hamayon 2001:13) versus that of society. This tension was already present in the original formulation of the hypothesis but it seems to have been finally resolved in favour of the individual (see Dowson 1988:125, LewisWilliams 2002:45). The initial concern to place rock art and individuals in their social context has been very much replaced by the notion of humans as essentially religious (and artistic) beings. ${ }^{11}$ In other words, the original premise concerned with the social relations in which the rock art was embedded (see, for instance, Lewis-Williams 1982, Dowson 1994, 1998) evolved into an 'explanation' of rock art by assigning particular meanings to the depictions. Individual genius, creativity and personal intentions (aspects that can or need not be explained), together with an allegedly universal predisposition towards religion and its practice, have become the ultimate explanation of the existence of rock art, that appears as the product of a myriad of individual independent events fundamentally disconnected from each other, that eventually formed the rock art corpus as we know it.

In a way, the use of the ethnographic records may promote such an approach to rock art as they are case by case accounts of depictions and of particular sites; as a result, researchers may end up with a collection of particular events. But, if we are going to attain the methodological tools necessary to explain its appearance as an extremely 
structured phenomenon, rock art must be explicitly defined as a social institution.

This was part of the original formulation of shamanism, as it was the contemplation of contradiction and rock art as a locus of struggle ('The rock art was one element in a dialectic of domination and resistance' (Dowson 1994:341)). This was in my view one of the best accomplishments of the shamanic approach, since researchers were able to reach social readings of rock art that still remain quite innovative; shamanism allowed a better understanding of the social formation that made the art. Actually, shamanism potentially promoted the practice of archaeology, as a means of independent verification. However, as it shifted towards a greater focus on religion and meaning, shamanism has been reduced in its scope both in content and method, since it reduces archaeological practice to a mere complement of ethnographic texts. ${ }^{12}$ Moreover, the use of ethnographic texts as 'translations' of archaeological objects, as opposed to actual analogical reasoning, potentially annihilates the possibility of contradiction between material culture and discourse.

\section{CONCLUSION}

Rock art is multidimensional: a product of ideological processes and relations, a symbolic phenomenon, a cultural correlate of social, economic and political processes. It must therefore be addressed from a complex point of view, one that transcends theoretical boundaries (between processual and post-processual archaeologies, between structuralist and historical materialist approaches, between materialism and idealism) and disciplines (anthropology, archaeology). In some cases, the use of direct ethnographic analogies may inhibit the development of more nuanced archaeological approaches given the wealth of detail they provide. Thus, ethnographic analogies may not always open new possibilities of research and interpretation; they do not widen the range of potential explanations for a given phenomenon but instead reaffirm existing ones and in this way the status quo.

This is the worst case scenario, of course. The epistemic value of analogy was established long ago (see Wylie 1985, Lane 2006) and analogical reasoning has helped to make rock art meaningful in its broader social context on many occasions. Ethnography has been a real peer to archaeology, especially in case studies where ethnographic data have been complemented with a strong interest in landscape, the location of the rock art and the patterns of association of rock art and other elements (Deacon 1988, Morwood \& Hobbs 1992, Smith 1992, Taçon \& Faulstich 1993, Bradley et al. 1994, Waddington 1996, Millerstrom 1997, Rosenfeld 1997, David \& Lourandos 1998, Martínez 1998, Santos 1999, Layton 2000, Lee \& Stasack 2005 [1999], Cruz Berrocal \& Vicent 2007). For these reasons, an anti-ethnography declaration is totally out of place. Rather, analogical reasoning and its implications must be made explicit (or what kind of analogy and how is being used), since building an analogy is one important way for rock art researchers (and archaeologists at large) to create their evidence.

The study of rock art is currently dominated by interpretative approaches that tend to rely on ethnographic analogy and place emphasis on grasping the concrete meanings of the depictions by way of an explanation. These approaches should be included within a higher-level contextualization of rock art. For instance, altered states of consciousness are social experiences that can be explained as part of regulatory social institutions. These, in turn may be understood within particular historical conditions. It is, therefore, specific social and historical contexts and the materiality of the paintings itself that represent relevant objects of research. Intersubjective judgement of the research, treating rock art as the expression of a social institution rather than as a particularistic activity and the analysis of our analogical thinking should all be part of the process of validating our results. 
This is especially so as nowadays mere iconographic descriptions, studies of representation and perspective, holistic explanations of territorial articulation and landscape construction and even demonstrations of a priori assumptions are all valid and equal outcomes of rock art research.

\section{ACKNOWLEDGEMENTS}

The core of this paper was written while I was a MEC/Fulbright postdoctoral scholar at UC Berkeley, 2007-2008. I thank Meg Conkey, Juan Vicent, Antonio Gilman and Leonardo García Sanjuán for their reading and comments. I warmly thank Janette Deacon and Maribel Martínez Navarrete for their clever and useful suggestions. Marcos Llobera thoroughly revised the paper and the English, improving it a great deal, for which I remain really thankful. Carmen Pérez, Teresa Rodríguez and Alex Suárez gave me a hand with pictures. Primitiva Bueno and Rodrigo de Balbín also provided bibliography. Reviewers of a previous version pointed out its weaknesses. Any mistake remains my own.

\section{NOTES}

${ }^{1}$ Shamanic practices or shamanic religion have been a widely debated topic in broader anthropological and historical contexts (see, e.g., Hamayon 1993, 1995, 1998, Kehoe 1996, 2000). Their relationship with the counter-culture movements of the 1960s has been pointed out (which, for instance, led some critics to see a link between drug use in the present and hypotheses about drug use in the past leading to the making of rock art (Meighan 1982:226)). Also the romanticized vision of the past turned out by shamanism has been criticized (Hamayon 2001:3). More problematically, it is generally assumed that there exist varying criteria behind almost every use of the concept.

${ }^{2}$ This paper is mostly focused on shamanism as it was presented and popularized by the work of J.D. Lewis-Williams. In his important paper of 1982, however, he did not use the term shamanism, instead referring to medicine men, trancers and healers (interestingly, two of his commentators assumed the shamanistic nature of these practices and even the term). 'Shamanism' would not be used as a label by Lewis-Williams until several years later (J. Deacon pers. comm.).

${ }^{3}$ Examples of which would be the idea of a membrane as an interface between two worlds and the use of hallucinogenic substances by shamans. The assumption of a separation of the sacred and profane spheres has also been represented as a Western construction (e.g. Bahn 1997, 2001) that should not be attributed to past peoples.

${ }^{4}$ This would be due to its failure to address the issue of cultural change over time, which promotes a view of southern African rock art as static and universal (McCall 2007:225).

${ }^{5}$ Ethnographic analogies can ultimately be either relational analogies, based on understanding the causal relationships between the variables that can be observed, or formal analogies, based on a straightforward comparison of some aspect of form or observable characteristics (Wylie 1985). But I will use the concept 'ethnographic analogy' to stress the source of the information employed in the analogy.

${ }^{6} \mathrm{~A}$ middle-range theory (MRT) is widely regarded as a useful means by which archaeologists can reconstruct human behaviour from a materialist and rationalist perspective. As defined by Binford ... this approach postulates that, if a strong correlation can be established between specific aspects of behaviour and specific aspects of material culture in the modern (actual) world, the presence of such material culture in the archaeological record allows the archaeologist to assume that the associated behaviours also were present in the past. The bridging or warranting argument, which establishes the relevance of the modern generalization for inferring past behaviour, is that of uniformitarianism. It is assumed that the correlation applies to all situations in which human cognitive and behavioural capacities were the same as those of modern human beings. The goal of middle-range theory is not to explain human behaviour but to infer it from material remains recovered from archaeological contexts' (Trigger 1995:450).

Or, an 'MRT is a body of theory (or methodology) which bridges the gap between our observation of the archaeological record and our interpretation of it as a cultural system - it provides the middle ground between unreflective observation and general theory ... Thus an MRT might have 
very general cross-cultural applicability, but its role in interpreting the past is as a bridge or methodological tool and is quite distinct from general social theory ... . In themselves ... middle range theories are as theoretical as any other theory and no more or less general than "general" social theory' (Lucas 2001:184-185).

${ }^{7}$ These representations can relatively easily be interpreted as shamans undertaking a spiritual transformation, based on the ethnographic records. But the relevance given to these depictions has been considered a bias of shamanism, because they are in a minority (Bahn 2001:76) and could also be interpreted as disguises used by hunters, as spirits or as other mythical creatures (Solomon 1998, 2001, 2008).

${ }^{8}$ Originally, shamanic practices did not imply altered states of consciousness (Hamayon 2001, Bahn 2001). Trance became a key component of shamanism for South African rock art researchers and their particular contribution to a definition of shamanic religion.

${ }^{9}$ 'Since the publication of "Signs of all times", researchers from various parts of the world have taken up the model as a tool for approaching the understanding of rock art. It is in this globalization of the model that potential dangers are found ... a further potential danger of the use of the model is the tendency to treat the entoptic component as the final explanation. Once it is realized that an art depicts entoptics, some people feel that there is little more to say. "Abstract" images, like painted and engraved entoptics, do, however, have cultural values and meanings' (Blundell 1998:9-10).

${ }^{10}$ But see Kosso (1991:626), who argued that middle-range theory and hermeneutic approaches have a 'common structure' and 'are fundamentally the same method'.

${ }^{11}$ It has been noticed that such a focus on the religious character of the art can contribute to regarding its makers as fundamentally different (Bahn 1997:64; see also Klein et al. 2001:229).

${ }^{12}$ It has been noticed that the turn to ethnography 'has at least two implications: first, it mandates that interpreters (and especially the followers of shamanism) confront explicitly the rather gnarly if not longstanding issue of the nature, role, and limits of ethnographic analogy in archaeological reasoning and interpretation; and second, it asks how rock art researchers can develop interpretive frameworks that draw from the rich bodies of theory - of representation, social agency, performance, semiotics and structuration, feminist theory, and so forth - that are unlikely to be considered in (sometimes problematic) ethnographies, but may be particularly well suited to the nature of rock art as a cultural phenomenon. Furthermore, what is painfully missing or limited in many of these approaches is the archaeology; that is, the use of archaeological materials and contexts, where available, to provide additional lines of evidence into understanding the (presumably dynamic and changing) social contexts within which shamanism, ritual, and trance, for example, would have been embedded' (Conkey 1997:170).

\section{REFERENCES}

Bahn, P. 1993. The 'dead wood stage' of prehistoric art studies. In Lorblanchet, M. \& Bahn, P. (eds). Rock Art Studies. The Post-Stylistic Era or Where Do We Go from Here?, pp. 51-59. Oxbow Books, Oxford.

Bahn, P. 1997. Membrane and numb brain. A close look at a recent claim for shamanism in Palaeolithic art. Rock Art Research 14(1), 62-68.

Bahn, P. 2001. Save the last trance for me. An assessment of the misuse of shamanism in rock art studies. In Francfort, H-P. \& Hamayon, R. in collaboration with P.G. Bahn (eds). The Concept of Shamanism. Uses and Abuses, pp. 51-93. Bibliotheca Shamanistica, Akadémiai Kiadó, Budapest.

Balbín Behrmann, R. de 2007. El chamanismo cabalga de nuevo. Una propuesta nueva de carácter tradicional sobre el arte prehistórico. Review article: M. Lorblanchet, J. Le Quellec, P. Bahn, H.P. Francfort and G. Delluc (dir.) Chamanismes et arts préhistoriques. Vision critique. Ed. Errance, Paris, 2006. Trabajos de Prehistoria 64(2), 182-184.

Balbín Behrmann, R. de \& Alcolea, J. 1999. Vie quotidienne et vie religieuse. Les Sanctuaires dans l'art Paléolithique. L'Anthropologie 103, 23-49.

Barich, B. 1996. Post processual archaeology and scientific objectivity. Implications for rock art research. Origini 20, 7-16.

Barton, C. M., Clark, G.A. \& Cohen, A. 1994. Art as information. Explaining Upper Palaeolithic art in Western Europe. World Archaeology 26(2), 185-204. 
Beaune, S. de 1998. Chamanisme et préhistoire. Un feuilleton à épisodes. L'Homme 147, 203-219.

Bertilsson, U. 1995. Rock art, recent research and religion. In Helskog, K. \& Olsen, B. (eds). Perceiving Rock Art. Social and Political Perspectives, pp. 207-214. Novus Forlag, Oslo.

Blundell, G. 1996. Book review: The Rock Art of the Golden Gate and Clarens District by Bert Woodhouse. William Waterman Publications: Rivonia. Southern African Field Archaeology 5 , 103-104.

Blundell, G. 1998. On neuropsychology in southern African rock art research. Anthropology of Consciousness 9(1), 3-12.

Bradley, R., Criado, F. \& Fábregas, R. 1994. Rock art research as landscape archaeology. A pilot study in Galicia, North-West Spain. World Archaeology 25(3), 374-390.

Clottes, J. \& Lewis-Williams, J.D. 1996. Les chamanes de la préhistoire. Transe et magie dans les grottes ornées. Seuil, Paris.

Conkey, M.W. 1980. The identification of prehistoric hunter-gatherer aggregation sites. The case of Altamira. Current Anthropology 21(5), 609-630.

Conkey, M.W. 1984. To find ourselves. Art and social geography of prehistoric hunter-gatherers. In Schrire, C. (ed.). Past and Present in HunterGatherer Studies, pp. 253-276. Academic Press, New York.

Conkey, M.W. 1985. Ritual communication, social elaboration, and the variable trajectories of Palaeolithic material culture. In Price, D.T. \& Brown, J. (eds). Prehistoric Hunter-Gatherers. The Emergence of Cultural Complexity, pp. 299 323. Academic Press, New York.

Conkey, M.W. 1989. The structural analysis of Palaeolithic art. In Lamberg-Karlovsky, C.C. (ed.). Archaeological Thought in America, pp. 135-154. Cambridge University Press, Cambridge.

Conkey, M.W. 1997. Making a mark. Rock art research. American Anthropologist 99(1), 168-172.

Conkey, M.W. \& Hastorf, C. (eds) 1990. The Uses of Style in Archaeology. Cambridge University Press, Cambridge.

Criado, F. \& Penedo, R. 1989. Cazadores y salvajes. Una contraposición entre el arte Paleolítico y el arte Postglaciar Levantino. Munibe 41, 3-22.
Cruz Berrocal, M. \& Millerstrom, S. 2010. Introduction to rock art and food producing societies. A systematic association. In Guidon, N., Buco, C. \& Simoes, M. (eds). Global Rock Art. Annals of the XVI World Congress of the International Federation of Rock Art Organizations, pp. 1359-1364. IFRAO, FUMDHAM, Piauí, Brazil.

Cruz Berrocal, M. \& Vicent García, J.M. 2007. Rock art as an archaeological and social indicator. The neolithisation of the Iberian Peninsula. Journal of Anthropological Archaeology 26, 676-697.

David, B. \& Lourandos, H. 1998. Rock art and socio-demography in northeastern Australian prehistory. World Archaeology 30(2), 193-219.

Deacon, J. 1988. The power of a place in understanding southern San rock engravings. World Archaeology 20(1), 129-140.

Demoule, J.P. 1997. Images prehistoriques, rêves de préhistoriens. Critique 606, 853-870

Dowson, T. 1988. Revelations of religious reality. The individual in San rock art. World Archaeology 20(1), 116-128.

Dowson, T. 1994. Reading art, writing history. Rock art and social change in southern Africa. World Archaeology 25(3), 332-345.

Dowson, T. 1998. Like people in prehistory. World Archaeology 29(3), 333-343.

Dowson, T. 2007. Debating shamanism in southern African rock art. Time to move on .... . South African Archaeological Bulletin 62(185), 49-61.

Francfort, H-P. 1998. Central Asian petroglyphs. Between Indo-Iranian and shamanistic interpretations. In Chippindale, C. \& Taçon, P. (eds). The Archaeology of Rock Art, pp. 302-318. Cambridge University Press, Cambridge.

Francfort, H-P. 2001a. Prehistoric section. An introduction. In Francfort, H-P. \& Hamayon, R. in collaboration with Bahn, P. (eds). The Concept of Shamanism. Uses and Abuses, pp. 31-49. Bibliotheca Shamanistica, Akadémiai Kiadó, Budapest.

Francfort, H-P. 2001b. Art, archaeology and the prehistories of shamanism in Inner Asia. In Francfort, H-P. \& Hamayon, R. in collaboration with Bahn, P. (eds). The Concept of Shamanism. Uses and Abuses, pp. 243-276. Bibliotheca Shamanistica, Akadémiai Kiadó, Budapest.

Francfort, H-P. \& Hamayon, R.N. in collaboration with Bahn, P. (eds). 2001. The Concept 
of Shamanism. Uses and Abuses. Bibliotheca Shamanistica, Akadémiai Kiadó, Budapest.

Gilman, A. 1984. Explaining the Upper Palaeolithic revolution. In Spriggs, M. (ed.). Marxist Perspectives in Archaeology, pp. 115-126. Cambridge University Press, Cambridge.

Hamayon, R.N. 1993. Are 'trance', 'ecstasy' and similar concepts appropriate in the study of shamanism? Shaman 1(2), 3-25.

Hamayon, R.N. 1995. Pour en finir avec la 'transe' et 'l'extase' dans l'étude du chamanisme. Etudes mongoles et sibériennes 26, 155-190.

Hamayon, R.N. 1997. La transe d'un préhistorien. A propos du livre de Jean Clottes et David Lewis-Williams. Les Nouvelles de l'Archaeologie 67, 65-67.

Hamayon, R.N. 1998. 'Ecstasy' or the Westdreamt Siberian shaman. In Wautscher, H. (ed.). Tribal Epistemologies, pp. 175-187. Aldershot, Avebury.

Hamayon, R.N. 2001. Shamanism. Symbolic system, human capability and Western ideology. In Francfort, H-P. \& Hamayon, R. in collaboration with Bahn, P. (eds). The Concept of Shamanism. Uses and Abuses, pp. 1-27. Bibliotheca Shamanistica, Akadémiai Kiadó, Budapest.

Helskog, K. 1999. The shore connection. Cognitive landscape and communication with rock carvings in northernmost Europe. Norwegian Archaeological Review 32(2), 73-94.

Helvenston, P. \& Bahn, P. 2004. Waking the trancefixed. Cambridge Archaeological Journal 14(1), 90-100.

Jochim, M. 1983. Palaeolithic cave art in ecological perspective. In Bailey, G. (ed.). HunterGatherer Economy in Prehistory. A European Perspective, pp. 212-219. Cambridge University Press, Cambridge.

Jolly, P. 1996. Symbiotic interaction between black farmers and south-eastern San. Implications for southern African rock art studies, ethnographic analogy, and hunter-gatherer cultural identity (with comments). Current Anthropology 37(2), 277-305.

Jones, A. 2003. Art and contestation: a review of K. Helskog, (ed.): Theoretical Perspectives in Rock Art Research. Novus Forlag, The Institute for Comparative Research in Human Culture, Oslo, 2001. Norwegian Archaeological Review 36(1), 77-80.
Kehoe, A. 1996. Eliade and Hultkranz. The European primitivism tradition. American Indian Quarterly 20(3), 377-392.

Kehoe, A. 2000. Shamans and Religion. An Anthropological Exploration in Critical Thinking. Waveland Press, Prospect Heights, IL.

Klein, C.F., Guzman, E., Mandell, E.C., StanfieldMazzi, M. \& Volpe, J. 2001. Shamanitis. A Precolumbian art historical disease. In Francfort, H-P. \& Hamayon, R. in collaboration with Bahn, P. (eds). The Concept of Shamanism. Uses and Abuses, pp. 207-41. Bibliotheca Shamanistica, Akadémiai Kiadó, Budapest.

Kosso, P. 1991. Method in archaeology. Middlerange theory as hermeneutics. American Antiquity 56(4), 621-627.

Lahelma, A. 2005. Between the worlds. Rock art, landscape and shamanism in subNeolithic Finland. Norwegian Archaeological Review 38(1), 29-47.

Lahelma, A. 2007. 'On the back of a blue elk'. Recent ethnohistorical sources and 'ambiguous' Stone Age rock art at Pyhänpäa, Central Finland. Norwegian Archaeological Review 40(2), 113-137.

Lane, P. 2006. Present to past. Ethnoarchaeology. In Tilley, C., Keane, W., Küchler, S., Rowlands, M. \& Spyer, P. (eds). Handbook of Material Culture, pp. 402-424. Sage, London.

Layton, R. 1995. Rereading rock art. Text and discourse. In Helskog, K. \& Olsen, B. (eds). Perceiving Rock Art. Social and Political Perspectives, pp. 217-227. Novus Forlag, Oslo.

Layton, R. 2000. Review feature. Shamanism, totemism and rock art. Les chamanes de la Préhistoire in the context of rock art research. Cambridge Archaeological Journal 10(1), 169-186.

Le Quellec, J-L. 2001. Shamans and Martians. The same struggle! In Francfort H-P. \& Hamayon, $\mathrm{R}$. in collaboration with Bahn, P. (eds). The Concept of Shamanism. Uses and Abuses, pp. 135-159. Bibliotheca Shamanistica, Akadémiai Kiadó, Budapest.

Lee, G. \& Stasack, E. 2005 [1999]. Spirit of Place. Petroglyphs of Hawai'i. Easter Island Foundation, Los Osos.

Leroi-Gourhan, A. 1992. L'art pariétal. Langage de la préhistoire. Editions Jérôme Millon, Grenoble. 
Lewis-Williams, J.D. 1980. Ethnography and iconography. Aspects of southern San thought and art. Man 15, 467-482.

Lewis-Williams, J.D. 1981. The thin red line. Southern San notions and rock paintings of supernatural potency. South African Archaeological Bulletin 36, 5-13.

Lewis-Williams, J.D. 1982. The economic and social context of southern San rock art. Current Anthropology 23(4), 429-449.

Lewis-Williams, J.D. 1984. The empiricist impasse in southern African rock art studies. South African Archaeological Bulletin 39, 58-66.

Lewis-Williams, J.D. 1991. Wrestling with analogy. A methodological dilemma in Upper Palaeolithic art research. Proceedings of the Prehistoric Society 57(1), 149-162.

Lewis-Williams, J.D. 1995a. Perspectives and traditions in southern African rock art research. In Helskog, K. \& Olsen, B. (eds). Perceiving Rock Art. Social and Political Perspectives, pp. 65-86. Novus Forlag, Oslo.

Lewis-Williams, J.D. 1995b. Some aspects of rock art research in the politics of presentday South Africa. In Helskog, K. \& Olsen, B. (eds). Perceiving Rock Art. Social and Political Perspectives, pp. 317-337. Novus Forlag, Oslo.

Lewis-Williams, J.D. 1996. Comment to Jolly, P. 1996. Symbiotic interaction between black farmers and south-eastern San. Implications for southern African rock art studies, ethnographic analogy, and hunter-gatherer cultural identity. Current Anthropology 37(2), 277-305.

Lewis-Williams, J.D. 1999. 'Meaning' in southern African San rock art. Another impasse? South African Archaeological Bulletin 54, 141-145.

Lewis-Williams, J.D. (ed.) 2000. Stories that Float from Afar. Ancestral Folklore of the San of Southern Africa. David Philip, Cape Town.

Lewis-Williams, J.D. 2002. The Mind in the Cave. Consciousness and the Origins of Art. Thames \& Hudson, New York.

Lewis-Williams, J.D. 2003. Putting the record straight. Rock art and shamanism. Antiquity 77(295), 165-170.

Lewis-Williams, J.D. 2004a. Neuropsychology and Upper Palaeolithic art. Observations on the progress of altered states of consciousness. Cambridge Archaeological Journal 14, 107-111.
Lewis-Williams, J.D. 2004b. On sharpness and scholarship in the debate on 'shamanism'. Current Anthropology 45(3), 404-406.

Lewis-Williams, J.D. 2006a. The evolution of theory, method and technique in southern African rock art research. Journal of Archaeological Method and Theory 13(4), 343-377.

Lewis-Williams, J.D. 2006b. Debating rock art. Myth and ritual, theories and facts. South African Archaeological Bulletin 61(183), 105-114.

Lewis-Williams, J.D. \& Dowson, T. 1988. The signs of all times. Entoptic phenomena in Upper Palaeolithic Art. Current Anthropology 29(2), 201-244.

Lewis-Williams, J.D. \& Dowson, T. 1992. Art rupestre San et paleolithique superieur. Le lien analogique. L'Anthropologie 96(4), 769-790.

Lewis-Williams, J.D. \& Clottes, J. 1998a. The Mind in the Cave-the Cave in the Mind. Altered Consciousness in the Upper Paleolithic. Anthropology of Consciousness 9(1), 13-21.

Lewis-Williams, J.D. \& Clottes, J. 1998 b. Shamanism and Upper Palaeolithic art. A response to Bahn. Rock Art Research 15(1), 46-50.

Lewis-Williams, J.D. \& Loubser, J. 1986. Deceptive appearances. A critique of southern African rock art studies. Advances in World Archaeology, Vol. 5, pp. 253-289. Academic Press, New York.

Lorblanchet, M. 2001. Encounters with shamanism. In Francfort, H-P. \& Hamayon, R. in collaboration with Bahn, P. (eds). The Concept of Shamanism. Uses and Abuses, pp. 95-115. Bibliotheca Shamanistica, Akadémiai Kiadó, Budapest.

Lucas, G. 2001. Critical Approaches to Fieldwork. Contemporary and Historical Archaeological Practice. Routledge, New York.

Martínez García, J. 1998. Abrigos y accidentes geográficos como categorías de análisis en el paisaje de la pintura rupestre esquemática. El sudeste como marco. Arqueología Espacial 1920, 543-561.

McCall, G.S. 2007. Add shamans and stir? A critical review of the shamanism model of forager rock art production. Journal of Anthropological Archaeology 26, 224-233.

Meighan, C. 1982. Rock art and archaeology. American Indian Rock Art 7-8, 225-229. 
Millerstrom, S. 1997. Carved and painted rock images in the Marquesas Islands, French Polynesia. Archaeology in Oceania 32, 181-196.

Mithen, S. 1987. Looking and learning. Upper Palaeolithic art and information gathering. World Archaeology 19(3), 297-327.

Mithen, S. 1991. Ecological interpretations of Palaeolithic art. Proceedings of the Prehistoric Society 57(1), 103-114.

Morwood, M. \& Hobbs, D. 1992. Rock Art and Ethnography. Proceedings of the Ethnographic Symposium 5, Australian Rock Art Association Congress (Darwin 1988).

Palacio Pérez, E. 2010. Cave art and the theory of art. The origins of the religious interpretation of Palaeolithic graphic expression. Oxford Journal of Archaeology 29(1), 1-14.

Robb, J. 2007. The Early Mediterranean Village. Agency, Material Culture, and Social Change in Neolithic Italy. Cambridge University Press, Cambridge.

Rosenfeld, A. 1997. Archaeological signatures of the social context of rock art. In Conkey, M., Soffer, O., Stratmann, D. \& Jablonski, N. (eds). Beyond Art. Pleistocene Image and Symbol, pp. 289-300. University of California Press, Berkeley.

Santos Estévez, M. 1999. A arte rupestre e a construccion dos territorios na idade do bronce en Galicia. Gallaecia 18, 103-118.

Sauvet, G. 1989. Further comment. Rock Art Research 6(2), 149-150.

Sauvet, G. \& Wlodarczyk, A. 1995. Éléments d'une grammaire formelle de l'art pariétal paléolithique. L'Anthropologie 99(2-3), 193-211

Smith, B. \& Ouzman, S. 2004. Taking stock. Identifying Khoekhoen herder rock art in southern Africa. Current Anthropology 45(4), 499-526.

Smith, C. 1992. The use of ethnography in interpreting rock art. A comparative study of art from the Arnhem Land and Western Desert regions of Australia. In Morwood, M. \& Hobbs, D. (eds). Rock Art and Ethnography. Proceedings of the First Australian Rock Art Research Association Congress, pp. 39-45. Australian Rock Art Research Association, Melbourne.

Solomon, A. 1998. Ethnography and method in southern African rock art research. In Chippindale, C. \& Taçon, P. (eds). The
Archaeology of Rock Art, pp. 268-284. Cambridge University Press, Cambridge.

Solomon, A. 2001. What is an explanation? Belief and cosmology in interpretations of southern San rock art in southern Africa. In Francfort, H-P. \& Hamayon, R. in collaboration with Bahn, P. (eds). The Concept of Shamanism. Uses and Abuses, pp. 161-77. Bibliotheca Shamanistica, Akadémiai Kiadó, Budapest.

Solomon, A. 2008. Myths, making, and consciousness. Differences and dynamics in San rock arts. Current Anthropology 49(1), 59-86.

Taborin, Y. 2000. Les interprétations de l'art paléolithique. Archéologia 366, 52-61.

Taçon, P. \& Faulstich, P. 1993. Introduction. Expressing relationships to the land by marking special places. In Steinbring, J. \& Watchman, A. (eds). Time and Space. Dating and Spatial Considerations in Rock Art Research, pp. 8183. Occasional AURA Publication 8, Australian Rock Art Research Association, Melbourne.

Tilley, C. 1991. Material Culture and Text. The Art of Ambiguity. Routledge, London.

Trigger, B. 1995. Expanding middle-range theory. Antiquity 69(264), 449-459.

Trigger, B. 1999. Reconnoitring religion. Cambridge Archaeological Journal 9(1), 139-141.

Vialou, D. 1998. Problématique de l'interprétation de l'art paléolithique. Rivista di Scienze Preistoriche 49, 267-281.

Vinnicombe, P. 1995. Perspectives and traditions in Australian rock art research. In Helskog, K. \& Olsen, B. (eds). Perceiving Rock Art. Social and Political Perspectives, pp. 87-103. Novus Forlag, Oslo.

Waddington, C. 1996 Putting rock art to use. A model of Early Neolithic transhumance in North Northumberland. Northern Archaeology 13-14, 147-177.

Whitley, D. 1994. Ethnography and rock art in the Far West. Some archaeological implications. In Whitley, D. \& Loendorf, L. (eds). New Light on Old Art. Recent Advances in Hunter-Gatherer Rock Art Research, pp. 81-93. Institute of Archaeology, UCLA, Los Angeles.

Whitley, D. 2001. Science and the sacred. Interpretative theory in US rock art research. In Helskog, K. (ed.). Art and Contestation. Theoretical Perspectives in Rock Art Research, pp. 130-157. Novus Forlag, Oslo. 
Whitley, D. 2005. Introduction to Rock Art Wylie, A. 1985. The reaction against analogy. In Research. Left Coast Press, Walnut Creek, CA.

Whitley, D. \& Keyser, J. 2003. Faith in the past. Schiffer, M. (ed.). Advances in Archaeological

Debating an archaeology of religion. Antiquity 77(296), 385-393. Academic Press, New York. 